\title{
Stuck between federalism and the vertical of power: Russian regions on the international arena*
}

\author{
A. Podleśny, A. Miazek \\ Uniwersytet Warszawski, \\ 26/28, Krakowskie Przedmieście, Warszawa, 00-927, Poland
}

For citation: Podleśny A., Miazek A. Stuck between federalism and the vertical of power: Russian regions on the international arena. Vestnik of Saint Petersburg University. International Relations, 2020, vol. 13, issue 3, pp. 423-426. https://doi.org/10.21638/spbu06.2020.309

\section{Significance of chosen research area}

Modern international relations are characterised by a rising significance of non-state or sub-national (sub-state) actors. Due to the process of globalization, cooperation between local and regional communities has become more and more important, especially when it comes to trans-border cooperation, a twin-city partnership and inter-regional relations. This kind of cooperation is mostly economic and social-cultural, with lesser importance of political issues. The rising significance of regions' subjectivity can be seen in growing numbers of their foreign representatives and amounts of financial resources related to their international activity as well.

Aspects of trans-border cooperation, both in Eastern Europe and Poland (especially in the euro-regions formula), are widely covered in Polish political science literature. There is also a relatively big amount of research concerning the functioning of units which are parts of federal countries (e.g., lands in Germany and their cooperation with Polish subjects) on the international stage. On the other hand, research concerning Russian specifics of regions' activeness is much more scarce. Even if works of this kind have appeared, they have been focused mainly on the Kaliningrad Oblast'.

The choice of the research area is therefore highly appropriate, mostly because of the fact of the rising role of international sub-national actors, but also due to the lack of similar research in Polish political studies.

\section{Formal assumptions}

In the Introduction the author defines the subject and the aim of the research, also formulating hypotheses and research questions. The subject of the research is the international activeness of basic administrative and territorial units of a country by the example of Russia after 1991 (p. 15). The international activity of the Russian Federation's regions is examined in this work, with special attention paid to its internal and external determi-

* Review Article of a Book: Raś, M. (2018), International Activity of the Russian Federation's Regions, Warsaw: ELIPSA Publ., 426 p.

(c) Санкт-Петербургский государственный университет, 2020 
nants, formal and legal foundations, range (subject of cooperation), methods of impact, types of internal partners, geographical directions and the evolution of international activities of Russian regions between 1991 and 2017 (p. 14).

Therefore, the Author's main objectives were: to compare Russian regions' participation in international relations to regions with similar formal status in selected federal countries; to indicate factors conditioning Russian regions' international activity; to evaluate ability of the Russian Federation's subjects to act internationally as well as their actions' impact on the development of the whole state; to analyse the diversification of these regions' international activity.

Putting research hypotheses, the author assumed that the Russian Federation's subjects have co-created the image of this country and participated in shaping its identity. The range and character of their international actions have had an impact on Russia's system transformation, at the same time reflecting political, social and economic changes in this country. Moreover, according to the author, Russian regions' engagement into the international affairs has contributed to the improvement relations between Russia and other countries. The author also assumed that the strengthening the federal power in Russia after 2000 has triggered significant modification (but not reduction) of these regions' international activity.

\section{Structure and content}

The monograph is consisted of introduction, five substantive chapters, conclusion, annex of the Russian Federation's regions, bibliography and index of names. The work's structure is subordinated to the research aims and hypotheses.

The first chapter (Regions as sub-national participants of international relations; p. 2187 ) is focused on the most important theoretical aspects related to the research area. The author discusses terminology connected with the subjects of research, putting emphasis on clarifying such terms as "region", "subnational region", "regionalization", "decentralization" and "international activity of regions" / "paradiplomacy". The subsequent part of this chapter is devoted to the characterising regions' international involvement as well as the state of research on discussed topic in English-language, worldwide literature and in Russia.

In the next chapter (Participation of the federal countries' regions in international relations; p. 89-141) the author identifies and analyses features of federal countries' regions as international actors. Moreover, international activity of Belgium's, Canada's, Germany's and the United States of America's regions is illustrated. The author rightly points to the fact that legal solutions in the Russian Federation ought to be treated as a model of paradiplomatic activity, which is characterized by a clear domination of the federal centre system over the federation's subjects. It results in creating most significant limitations in terms of creating and realizing contacts with foreign countries.

The third chapter is focused on Factors shaping international actions of the Russian Federation's regions (p. 143-200). The author discusses the historical perspective influencing this phenomenon, considering Russia's system transformation after 1991, in particular. Processes related to the creation of the Russian Federation's national and international identity and the evolution of Russian federalism are consequently analysed. The last but not least, the variability of Russian regions' international strategies and actions is considered. 
The author analyses Russian regions' international competences in the fourth chapter (Russian regions' ability to international impact and its influence on the country's development; p. 201-244). He points out the direct and indirect methods of the regions' international influence in details, presenting a classification of Russian regions in the context of their participation in the international relations as well. It serves also to analyse the impact of regions' international actions on the development, cohesion and foreign policy of the Russian Federation. The author shows a great knowledge on the legal aspects of Russian regions' politics, showing the evolution of their status since the collapse of the USSR until today. The comparative analysis related to the examples of other federal countries is another advantage of this work. The author emphasise the fact that the main factors, determining the scale of specific regions' international activity, are material and intellectual potential, geographical location, the position presented by regional elites as well as regional identity.

In the last chapter the subject of Diversity of chosen Russian Federation regions' international activity (p. 245-376) is traced. The author analyses and compares foreign activity of some regions: Moscow and Petersburg (the Russias "windows to the world"), the Republic of Karelia and the Kaliningrad Oblast' (a cooperation alongside the Russia-European Union borders), the "Russia's South" (the Krasnodar Krai and the North Caucasus autonomous republics) as well as the Russian Far East' regions. The analysis of the diversity of their activity is done on the basis of a case study with elements of comparative analysis which leads to the author's generalisations and conclusions. He underlines that the diversification of the Russia's regions international actions causes the creation of international contacts of a different nature and with different aims.

The Conclusion (p. 377-381) includes general statements about Russian regions' international activity which are based on the research outcomes presented in the previous chapters. The author concludes, for instance, that regions co-decided about Russia's image and identity, being the same time dependent on nationwide political and socio-economical processes (p. 377). The author claims that Russian regions' international activity has been significantly developed since the beginning of the 90 's, being much better organised and synchronised with the federal policy nowadays than in the first decade of the "new Russia". He also highlights a more pragmatic character of the regions' international activity in the $21^{\text {st }}$ century, which leads to its better effectiveness despite growing formal and informal federal center's control (p. 381). There is also a conclusion that the phenomenon requires further research, which should take into particular consideration the dynamics of internal and external determinants of these actions.

\section{Conclusion}

Summing up, it should be emphasised that the subject of research is unique in Polish scientific literature. It is an attempt of dealing with an ambitious research question which requires broad knowledge not only about the Russian Federation, but also about other aspects of international relations. The book has a broad multilingual bibliography (mostly in Russian, English and Polish) which includes legislative acts and other documents, books, scientific journals, various papers and reports as well as numerous internet sources. The work is also enriched with the author's observations (including participant observation) and his interviews with Russian interlocutors. 
The author has accomplished his research aims, correctly applying research methods: statistical methods are used to examine activities of Russian regions in the international economic relations, legal and institutional analysis deals with investigating formal and legal foundations of paradiplomatic activities, and comparative analysis is used to study the diversity of particular subjects' activities, also to compare them with other federal countries. The research hypotheses are positively verified. The author gives a satisfying answer to the questions formulated in Introduction.

However, some critical statements have to be made at this point. The author does not devote a separate chapter to the methodological aspects. This fact gives the impression that these issues may have been treated too generally. A number of them are dealt with in the Introduction, while the rest in the first chapter (terminology, theories, theoretical approaches). What is more, the research is not fully rooted in IR theory. The Author does present the current state of knowledge about the discussed field and points to the area of interest in the international relations studies. but the theoretical foundations are not explicitly pointed.

The monograph shows the importance of the regions' international activity for both foreign and domestic policy in Russia, pointing to the fact that it has been significant when it comes to some of the country's diplomatic actions. The author determines valuable caesuras, drawing the reader's attention to the key points of establishing regions' positions related to their foreign actions. There is also an interesting statement that, since Vladimir Putin's coming into power, the international role of regions has been changed but not reduced despite the attempts to consolidate the federal power.

Worth noticing that, while studying the legislative acts, the author does not only interpret them literally but also attempts to show particular legal solutions in the whole political system and verifies their practical introduction.

The characteristics of chosen regions' international actions in the context of previously discussed issues is the most interesting part of the monograph. It required very good knowledge of political, economic, cultural and social specifics of particular regions to achieve such a satisfying results. The author shows analytical skills which allow him to connect given facts with events reach a conclusion basing on this process. Although, the Republic of Tatarstan should have been given a wider attention, due to its importance and specifics in Russia's political system. A broader analysis of international actions of this region would be useful to complete the analysis.

Concluding, it should once again be emphasized that the work is an original attempt to study this research area, it has a important cognitive value and it tells a lot about the author's scholar maturity. The monograph fits the modern tendencies of international studies, which take not only topics of countries and organizations and their activities, but also focuses on sub-national and non-state subjects.

Received: April 9, 2020

Accepted: June 15, 2020

Authors' information:

Artur Podleśny - Postgraduate Student; a.podlesny@student.uw.edu.pl

Artur Miazek - Postgraduate Student; artur.miazek@wp.pl 